\title{
Blood rheological and electrical properties and relationships with the microvascular tone regulation in patients with diabetes mellitus type 2
}

\author{
${ }^{1}$ Dept. of Biomechanics, Institute of Mechanics, Bulgarian Academy of Sciences, Sofia, Bulgaria \\ ${ }^{2}$ Clinic of Nervous Diseases, Uni Hospital, Panagyurishte, Bulgaria \\ E-mail: antonova@imbm.bas.bg
}

Received 25.11.20; accepted 22.01.21

\section{Summary}

Aim. The study aims to evaluate impairment of the rheological and electrical properties of blood, plasma viscosity and blood conductivity in patients with type 2 diabetes mellitus (T2DM) in comparison with the data of the control group of healthy individuals. It also aims to investigate the changes of the skin blood flow responses to cold stress in T2DM patients through wavelet analysis of the peripheral skin temperature pulsations and to estimate their relationships with the blood viscosity and blood conductivity parameters, obtained from the simulation of experimental data with mathematical equations. Materials and methods. The whole blood viscosity was measured by Contraves LS30 viscometer (Switzerland) at a steady flow in 9 healthy individuals and in 13 patients with type 2 diabetes mellitus. Time variation of whole blood conductivity $\sigma$ under transient flow at rectangular and trapezium shaped Couette viscometric flow and under electric field of $2 \mathrm{kHz}$ was determined. The amplitudes of the skin temperature pulsations (ASTP) were monitored by «Microtest» device («FM-Diagnostics», Russia). To analyze the temperature fluctuations, wavelet transformation analysis of the low amplitude oscillations of skin temperature in accordance with myogenic $(0.05-0.14 \mathrm{~Hz})$, neurogenic $(0.02-0.05 \mathrm{~Hz})$, and endothelial $(0.0095-0.02 \mathrm{~Hz})$ control mechanisms of the vascular tone (WAST method) was applied. Results. Blood viscosity was increased in the T2DM patients' group, while blood conductivity decreased in comparison to controls. Two sigmoidal equations were applied to describe the kinetics of blood conductivity. Both models include conductivity indices $\left(\sigma_{1}, \sigma_{2}, \sigma_{3}\right)$ and time indices too. The Pearson correlations between these parameters and the ASTP in the frequency ranges, corresponding to the myogenic, neurogenic and endothelial mechanisms of the microcirculation tone regulation were analyzed. The correlation analysis revealed good ASTP $-\left(\sigma_{1}, \sigma_{2}, \sigma_{3}\right)$ relationships in the neurogenic range 3 minutes after the cold test, while the ASTP- $\left(\sigma_{1}, \sigma_{2}, \sigma_{3}\right)$ correlation in the myogenic frequency range before the cold test was negative $(\mathrm{r}<-0.8, \mathrm{p}<0.5)$. Conclusion. The results complement the studies of the microvascular regulatory mechanisms and endothelial dysfunction in patients with type 2 diabetes mellitus, as well as their relationships with the rheological and electrical properties of blood.

Keywords: diabetes mellitus type 2, skin temperature pulsations, contralateral cold test, microvascular tone regulation, blood and plasma viscosity, blood conductivity, mathematical equations

For citation: Antonova N. M., Paskova V. K., Velcheva I. V. Blood rheological and electrical properties and relationships with the microvascular tone regulation in patients with diabetes mellitus type 2. Regional blood circulation and microcirculation. 2021;20(1):25-33. Doi: 10.24884/1682-6655-202120-1-25-33.

Y $\triangle \mathrm{K} 612.1 ; 591.11 ; 577.353$

DOI: 10.24884/1682-6655-2021-20-1-25-33

\section{Н. М. АНТОНОВА' ${ }^{1}$, В. К. ПАСКОВА 1 , И. В. ВЕАЬЧЕВА}

\section{Реологические и электрические свойства крови и взаимосвязь с регуляцией тонуса микрососудов у пациентов с сахарным Аиабетом II типа}

\footnotetext{
${ }^{1} \Delta$ еп. биомеханики, Институт механики Бомгарской акахемии наук, София, Бомгария

${ }^{2}$ Клиника нервных болезней, Уни госпиталь, Панагюриште, Болгария

E-mail: antonova@imbm.bas.bg
}

\section{Резюме}

Статья поступила в редакциию 25.11.20; принята к печати 22.01.21

Цель - исследование направлено на оценку нарушения реологических и электрических свойств крови, вязкости плазмы и проводимости крови у пациентов с сахарным диабетом II типа (СД2) в сравнении с данными контрольной группы здоровых лиц. При этом также проводили изучение, на основе вейвлет-анализа пульсаций температуры кожи, реакций кожного кровотока на холодовую нагрузку у пациентов с СД2. Выполняли оценку взаимосвязи указанных выше параметров с показателями вязкости и проводимости крови, полученными в результате моделирования экспериментальных данных математическими уравнениями. Материальы и методы. Вязкость цельной крови измеряли вискозиметром Contraves LS30 (Швейцария) у 9 здоровых лиц и у 13 пациентов с СД2. Определяли изменение во 
времени электрической проводимости цельной крови б при нестационарном течении в прямоугольном и трапециевидном вискозиметрическом потоке Куэтта, при электрическом поле 2 кГц. Амплитуды пульсаций температуры кожи (АСТК) регистрировали прибором «Микротест» («ФМ-Диагностика», Россия). Был использован метод вейвлет-анализа низкоамплитудных колебаний температуры кожи в соответствии с миогенным $(0,05-0,14$ Гц $)$, нейрогенным $(0,02-0,05$ Гц) и эндотелиальным (0,0095-0,02 Гц) механизмами контроля тонуса сосудов (WAST-метод). Результаты. Вязкость крови увеличилась в группе пациентов с СД2, тогда как ее электрическая проводимость снизилась по сравнению с контролем. Для описания кинетики проводимости крови применяли два сигмоидальных уравнения. Обе модели включают индексы проводимости $\left(\sigma_{1}, \sigma_{2}, \sigma_{3}\right)$, а также временные индексы. Проанализированы корреляции Пирсона между этими параметрами и ASTP в частотных диапазонах, соответствующих миогенным, нейрогенным и эндотелиальным механизмам регуляции тонуса микроциркуляции. Корреляционный анализ выявил хорошие отношения $\mathrm{ASTP}-\left(\sigma_{1}, \sigma_{2}, \sigma_{3}\right)$ в нейрогенном диапазоне через 3 мин после холодового теста, в то время как корреляция ASTP $-\left(\sigma_{1}, \sigma_{2}, \sigma_{3}\right)$ в миогенном частотном диапазоне до холодового теста была отрицательной $(\mathrm{r}<-0,8, \mathrm{p}<0,5)$. Заключение. Результаты дополняют исследования механизмов регуляции микрососудов и эндотелиальной дисфункции у пациентов с сахарным диабетом II типа, а также их взаимосвязи с реологическими и электрическими свойствами крови.

Ключевые слова: сахарный диабет II типа, пульсации температуры кожи, контрлатеральная холодовая проба, регуляция тонуса микрососудов, вязкость крови и плазмы, проводимость крови, математические уравнения

Для цитирования: Антонова Н. М., Паскова В. К., Вельчева И. В. Реологические и электрические свойства крови и взаимосвязь с регуляцией тонуса микрососудов у пациентов с сахарным диабетом II типа. Регионарное кровообращение и микроциркуляция. 2021;20(1):25-33. Dоі: 10.24884/1682-6655-2021-20-1-25-33.

\section{Introduction}

The blood rheological properties have important role in ensuring blood circulation, along with neurogenic and humoral regulation, and properties of the vascular wall. In our previous studies we found that in the patients with diabetes mellitus type 2 (T2DM) the impairment of the cutaneous microvascular blood flow hemodynamic responses and the temperature oscillations were associated with increase of the blood viscosity values $[1,2]$.

Along with other optical methods a laser Doppler flowmetry is used to investigate the microcirculation [3]. This method provides useful information about the local skin factors of the microcirculatory regulation [4]. It was proved that the myogenic oscillation frequency spectrum of the vascular wall tone is $0.05-0.14 \mathrm{~Hz}$, the neurogenic activity is in the range of 0.02 to $0.05 \mathrm{~Hz}$ and the vascular endothelial function is determined in the spectrum of $0.0095-0.02 \mathrm{~Hz}$. Changes of the vascular tone influence the blood flow and cause the appearance of low-amplitude fluctuations in the temperature on the skin surface $[5,6]$. A statistically significant correlation between the variations in the skin temperature and the blood flow changes recorded by Doppler flowmetry has been established $[7,8]$. This allows the use of wavelet analysis of temperature variations on the skin surface for analysis of the dynamics of the vascular tone in the frequency bands resulting for myogenic and neurogenic activity, as well as for functioning of the endothelium $[6,9,10]$.

In our previous studies the oscillations in the skin temperature after cold test in patients with T2DM, the blood rheological properties and the relationship with disturbances of the microvascular tone regulation were analyzed $[9,10]$.

It was found that the electrical properties of the flowing blood depend on the flow conditions and the modes (regimes) of the applied shear rates. The reason is the erythrocyte orientation and deformation under flow, erythrocytes' slightly electronegative charge, the hematocrit and the different shear rates [11]. It was also shown that the blood conductivity is a very sensitive tool and that the RBCs aggregation-disaggregation processes can be characterized by measuring the electrical conductivity of blood under conditions of non-steady viscometric flow [12].

The present study aims through novel approaches, methods and tools to study impairments of the rheological and electrical properties of the blood and plasma viscosity and blood conductivity under different flow conditions and modes of steady and unsteady flow in a group of patients with T2DM and in a control group of healthy subjects. Another aim is to analyze the peripheral vasomotor reactivity and vascular endothelial function in these patients using the wavelet analysis of skin temperature oscillations (WAST) method. The last aim is to analyze the data obtained using mathematical models and to seek correlations, characterizing the relationships between the blood rheological parameters and the micromechanical properties of the blood cells as well as the parameters of microvascular tone regulation in T2DM patients.

\section{Materials and methods Subjects}

The study included 13 patients ( 9 women and 4 males, mean age $66.92 \pm 11.10$ years) with T2DM with mean duration of the disease $12.33 \pm 5.3$ years and 9 healthy controls ( 8 women and 1 male, mean age $52.3 \pm 9.4$ years). The diagnosis of T2DM was based on clinical examination and estimation of blood glucose, insulin and HbA1C. The clinical examinations of the patients were performed in the University Hospital of Neurology and Psychiatry «St. Naum», Medical University in Sofia, Bulgaria. Blood samples were collected in Li heparin tubes and rheological measurements were completed within 3 hours after the blood sample withdrawal. Both groups gave voluntary informed consent to participate in the study.

Biochemical and hematological examinations. The examined hemorheological blood constituents were: hematocrit (Ht), fibrinogen (FIB), erythrocytes (Erythr), platelets (Plt), mean cell volume (MCV). The relationship between the dynamic viscosity and Ht, Fib, Erythr and MCV were evaluated using the correlation coefficient $r$. The mean hematocrit values of the studied groups were: $\mathrm{Ht}(\mathrm{T} 2 \mathrm{DM})=38.9 \pm 5.04 \%$; Ht $($ controls $)=42.7 \pm 1.82 \%$ 


\section{Methods}

Statistical analyses were performed using the scientific graphing and data analysis software packages SigmaPlot 11.0 (Systat Software Inc., 2008) и Origin 6.1 (OriginLab Corporation, 2009). The data were presented as mean \pm standard deviation (SD). According to normality of the data distribution (Shapiro - Wilk's W test) the significance of inter-group differences was evaluated by using the Student's t-test and Mann Whitney U test. Pearson correlation coefficient was used to evaluate the relationship between the whole blood conductivity, the hemorheological and the microrheological parameters and the parameters obtained for the amplitudes of the skin temperature pulsations (ASTP). A p value less than 0.05 was considered as statistically significant.

Rheological and electrorheological measurements. A rotational viscometer Contraves LS30 (Switzerland) with MS 1/1 standard measurement system and the concurrent measuring system MS $1 / 1$ was used to investigate the rheological and electrical properties of blood simultaneously [11]. Whole blood viscosity (WBV) was examined under conditions of a steady blood flow at 12 shear rates from $0.0237 \mathrm{~s}^{-1}$ to $94.5 \mathrm{~s}^{-1}$ at $37^{\circ} \mathrm{C}$.

A method based on dielectric properties of dispersed systems in Couette viscometric blood flow was applied to investigate the kinetics of $\mathrm{RBC}$ aggregation and the formation and break-up of the aggregates. Time variation of whole blood conductivity $\sigma$ and shear stresses under transient flow at rectangular and trapezium shaped Couette viscometric flow were investigated under electric field of $2 \mathrm{kHz}$. To investigate aggregation process in stasis and under flow conditions after subjected to shearing for 30 seconds to disperse all aggregates, RBC suspension was stopped or decreased to allow RBCs aggregation. Immediately after beginning and complete stoppage of shearing kinetics of conductivity and torque signals were recorded. If the higher shear rates had no further effect on $\sigma$ values measured during shearing, the applied shear rate was sufficiently high for complete dispersion of the aggregates [11, 12].

Equations. The obtained experimental data on the kinetics of the whole blood conductivity in both studied groups of T2DM patients and of controls were described by the following equations, derived in our previous studies [11] and used for estimation of RBC aggregation-disaggregation process at loading (1) and at relaxation (2).

$$
\sigma=\frac{\left(\sigma_{1}-\sigma_{2}\right)}{1+\left(t / t_{0}\right)^{p}}+\sigma_{2}
$$

where $\sigma_{1}$ is the initial value of the blood conductivity; $\sigma_{2}$ is the final value of the blood conductivity; $\mathrm{p}$ is power and $t_{0}$ is the center of the curve.

$$
\sigma=\sigma_{3}+\frac{\left(\sigma_{2}-\sigma_{3}\right) f}{1+10^{t-\log t_{01}}}+\frac{\left(\sigma_{2}-\sigma_{3}\right)(1-f)}{1+10^{t-\log t_{02}}}
$$

where $\sigma_{2}$ is the initial asymptotic value of the blood conductivity; $\sigma_{3}$ is the final asymptotic value of the blood conductivity; $0<\mathrm{f}<1$ is a fraction and $t_{01}$ and $t_{02}$ are first and second curve centers.
Based on the blood viscosity experimental data the index of erythrocyte aggregation (IAE) index, characterizing the erythrocyte aggregation and $\mathrm{T}_{k}$ index, characterizing erythrocyte deformability were calculated. The IAE is determined as the relation of whole blood viscosity at $11,02 \mathrm{~s}^{-1}$ to whole blood viscosity at $94,5 \mathrm{~s}^{-1}$ [13].

$$
I A E=\frac{\eta_{11,02}}{\eta_{94,5}} .
$$

$\mathrm{T}_{\mathrm{k}}$ index characterizes the erythrocyte deformability [14]. It is determined by the relation:

$$
T_{k}=\frac{\eta_{r}^{0.4}-1}{\eta_{r}^{0.4} \cdot H t},
$$

where $\eta_{r}$ is the relative viscosity; $\eta_{r}=\eta_{b} / \eta_{p p} \eta_{b l}$ is the apparent dynamic blood viscosity at shear rate $94.5 \mathrm{~s}$ ${ }^{1}$ and $\eta_{p l}$ is plasma viscosity at the same shear rate, $\mathrm{Ht}, \%$ is the hematocrit [14].

Skin temperature oscillations recording. Recording of the skin temperature on the volar surface of the distal phalange of the $2^{\text {nd }}$ finger under basal conditions $10 \mathrm{~min}$, during a 3 min immersion of the contralateral hand in ice water and $10 \mathrm{~min}$ thereafter by means of platinum thermistor sensor is performed.

The amplitudes of the skin temperature pulsations (ASTP) were monitored by «Microtest» device («FMdiagnostics», Russia) providing the actual resolution of temperature is $0.002{ }^{\circ} \mathrm{C}$. The operating principles of the «Microtest» device are based on the recording the low-amplitude fluctuations of the skin temperature caused by change of the microvascular tone in the skin with a high temperature resolution. To analyze the temperature fluctuations innovative wavelet-analysis algorithms were used with Wavelet transformation analysis of the low amplitude oscillations of the skin temperature in accordance with myogenic $(0.05-0.14$ $\mathrm{Hz})$, neurogenic $(0.02-0.05 \mathrm{~Hz})$, and endothelial $(0.0095-0.02 \mathrm{~Hz})$ control mechanisms of the vascular tone $[6,8,15]$.

Contralateral cold test. The patients were in supine position during the contralateral cold test. The measurements were conducted at room temperature $22.5 \pm 0.5^{\circ} \mathrm{C}$. The skin temperature was recorded on the palm surface of the index distal phalanx of the right hand. The thermal sensor has low-conductive enclosure to prevent the influence of ambient air flows. Another sensor controls the room temperature.

During the cold test, the left hand was immersed into ice-water mixture at $0{ }^{\circ} \mathrm{C}$ for $3 \mathrm{~min}$. Skin temperature was continuously measured for $10 \mathrm{~min}$ before the test, 3 min during the test and $10 \mathrm{~min}$ after the cooling. The temperature recording started after the establishment of a stationary thermal regime, approximately $5-10 \mathrm{~min}$ after the sensor attachment. The minimal initial skin temperature to find reliable response to cold test was $30^{\circ} \mathrm{C}[1,2,6,8,15]$.

\section{Results}

A comparison of the mean whole blood viscosity values (WBV) of the diabetic patients with the mean WBV of the control group and their standard deviations within the wide range of shear rates is shown in Table 1. 
ОРИГИНААЬНЫЕ СТАТЬИ (кАинические исслеАования) / ORIGINAL ARTICLES (clinical investigations)

Mean values and standard deviations of whole blood viscosity (WBV) at different shear rates in the group of patients with diabetes mellitus type $2(n=13)$ and in healthy subjects $(n=9)$ [15]

\begin{tabular}{|c|c|c|}
\hline Shear rate $[s-1]$ & $\eta$ diabetes [mPa.s], mean \pm SD & $\eta$ controls [mPa.s], mean \pm SD \\
\hline 0.0237 & $65.73 \pm 15.18$ & $58.56 \pm 4.59$ \\
\hline 0.0596 & $50.92 \pm 12.09$ & $40.03 \pm 4.29$ \\
\hline 0.1102 & $47.28 \pm 13.58^{\star *}$ & $29.86 \pm 3.41$ \\
\hline 0.277 & $38.63 \pm 11.42^{* *}$ & $22.81 \pm 3.33$ \\
\hline 0.512 & $32.49 \pm 11.19^{*}$ & $21.46 \pm 3.21$ \\
\hline 1.285 & $22.18 \pm 6.95^{\star *}$ & $13.78 \pm 2.96$ \\
\hline 2.37 & $18.84 \pm 5.52$ & $13.38 \pm 2.74$ \\
\hline 5.96 & $12.94 \pm 3.21$ & $9.95 \pm 1.75$ \\
\hline 11.02 & $8.28 \pm 2.80$ & $7.99 \pm 0.97$ \\
\hline 20.40 & $8.00 \pm 1.66^{*}$ & $6.72 \pm 0.7$ \\
\hline 51.20 & $6.14 \pm 1.10$ & $5.38 \pm 0.55$ \\
\hline 94.5 & $5.37 \pm 0.87^{\star}$ & $4.63 \pm 0.44$ \\
\hline
\end{tabular}

${ }^{\star}-\mathrm{p}<0.05 ;{ }^{*}-\mathrm{p}<0.01$ significance in comparison to controls.

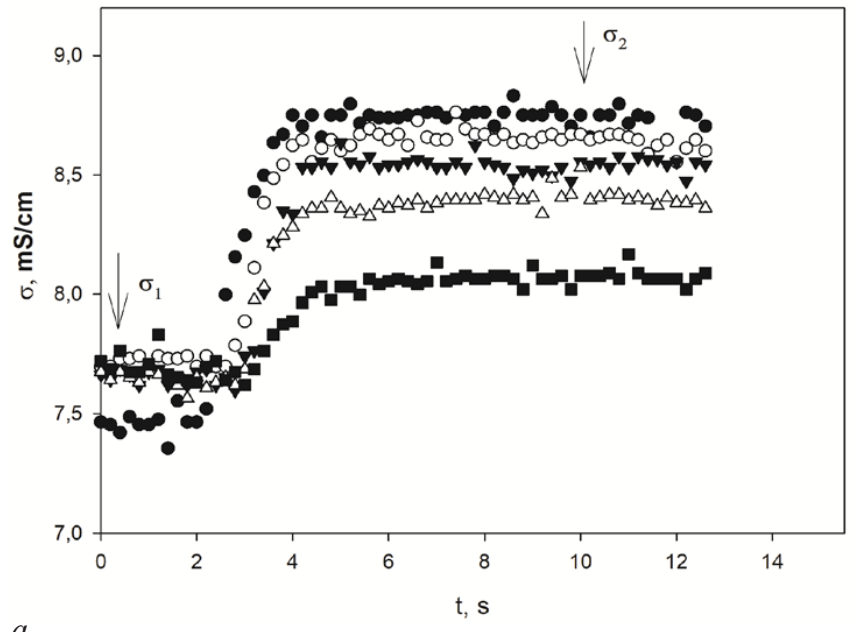

Fig. 1. Experimental data for blood conductivity in a patient obtained by rectangular regimes of the shear rates from $0 \mathrm{~s}^{-1}$ to $94.5 \mathrm{~s}^{-1}$, $37,6 \mathrm{~s}^{-1}, 20,4 \mathrm{~s}^{-1}, 11,02 \mathrm{~s}^{-1}, 3,23 \mathrm{~s}^{-1}(a)$ and back $(b)$ of whole blood, $\mathrm{H}=40,1 \%, \mathrm{~T}=37^{\circ} \mathrm{C}[15]$

An increase in the mean values of WBV in the group of T2DM patients was observed $[15,16]$. Statistically significant differences were found between the T2DM and the control groups at the shear rates of $0.1102 \mathrm{~s}^{-1}$ $(\mathrm{p}<0.01), 0.277 \mathrm{~s}^{-1}(\mathrm{p}<0.01), 0.512 \mathrm{~s}^{-1}(\mathrm{p}<0.05), 1.285 \mathrm{~s}^{-1}$ $(\mathrm{p}<0.01), 20.4 \mathrm{~s}^{-1}(\mathrm{p}<0.05)$ and $94.5 \mathrm{~s}^{-1}(\mathrm{p}<0.05)$, shown in Table 1. It was observed that the plasma viscosity was also increased in the patients' group as compared to the controls. Statistically significant differences for the plasma viscosity were observed at shear rates $-5.96 \mathrm{~s}^{-1}$, $51.20 \mathrm{~s}^{-1}$ and $94.5 \mathrm{~s}^{-1}(\mathrm{p}<0.05)$ [15].

Typical experimental dependences of whole blood conductivity at loading are shown on Fig.1, $a$. Starting from zero, the shear rates are increased up to $3,23 \div 94,5$ $\mathrm{s}^{-1}$ and the experimental data of the kinetics of blood conductivity at loading (Fig. 1, $a$ ) are recorded. These records are approximated by equation (1) and the mean values of its parameters, determined from the experimental data are presented in Fig 3. The results show that the mean values of the parameters of whole blood

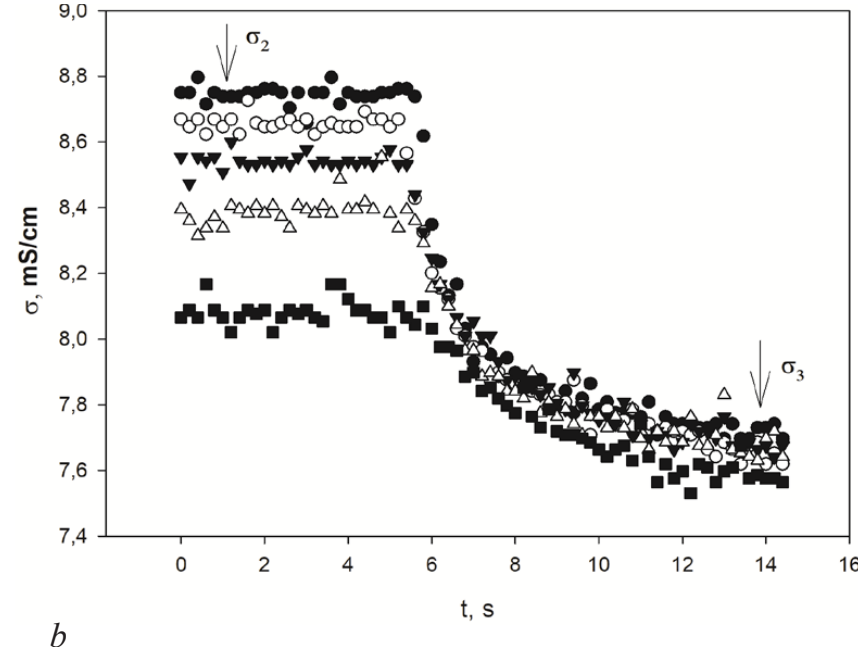

conductivity $\left(\sigma_{1}, \sigma_{2}\right)$, obtained from eq. (1) at loading from zero up to five different shear rates in the group of T2DM patients are lower than in the control group of healthy subjects (Fig. 3).

The experimental data for blood conductivity - time dependences at relaxation, starting from five different shear rates within the range $94,5 \div 3,23 \mathrm{~s}^{-1}$ and then back to zero (Fig. 1, $b$ ) are recorded. These data are simulated by the equation (2) and the mean values of its parameters are presented in Fig 4. The results show that the mean values of the parameters of whole blood conductivity $\left(\sigma_{2}, \sigma_{3}\right)$, obtained from eq. (2) at relaxation from five different shear rates to zero in the group of T2DM patients $(n=13)$ are also lower than in the control group of healthy subjects $(n=9)$.

The amplitudes of the skin temperature pulsations (ASTP) were monitored by «Microtest» device («FMDiagnostics», Russia). To analyze the temperature fluctuations wavelet transformation analysis of the low amplitude oscillations of skin temperature in accordance 

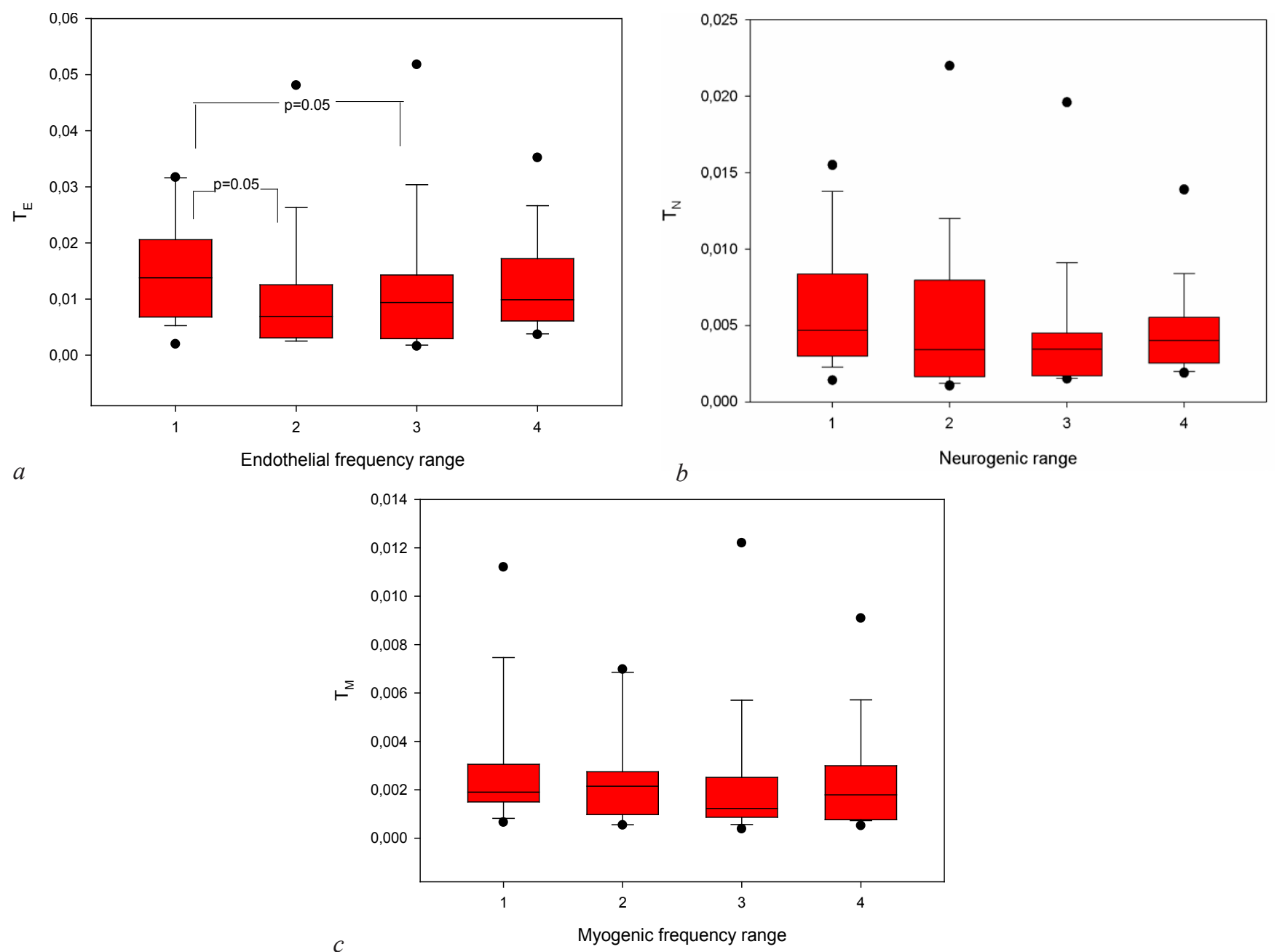

Fig. 2. Box-plot diagrams of the amplitudes of the skin temperature pulsations (ASTP) in the T2DM patients' group: $a$-in the endothelial $\left(\mathrm{T}_{\mathrm{E}}\right), b$ - neurogenic $\left(\mathrm{T}_{\mathrm{N}}\right), c$ - myogenic frequency ranges $\left(\mathrm{T}_{\mathrm{M}}\right)$

with myogenic $(0.05-0.14 \mathrm{~Hz})$, neurogenic $(0.02-$ $0.05 \mathrm{~Hz})$, and endothelial $(0.0095-0.02 \mathrm{~Hz})$ control mechanisms of the vascular tone (WAST method) was applied. The distribution of the obtained values of the root mean square (RMS) of the amplitudes of the skin temperature pulsations (ASTP) in the T2DM patients' group are shown as box-plot diagrams (Vertical Boxplot) on Fig. 2: $(a)$ in the endothelial $\left(\mathrm{T}_{\mathrm{E}}\right),(b)-\operatorname{neurogenic}\left(\mathrm{T}_{\mathrm{N}}\right)$ and $(c)$ - myogenic frequency ranges $\left(\mathrm{T}_{\mathrm{M}}\right)$. The median of the sample (straight black line), the confidence interval $(25-75 \%)$ and the obtained minimum and maximum value (errors) are shown on the figure. Statistically significant differences $(p<0.05)$ were found only in the endothelial frequency range $\left(\mathrm{T}_{\mathrm{E}}\right)$ : before the cold test, during the cold test and 3 minutes after it $(\mathrm{p}<0.05)$ in the T2DM group (Fig. 2, a).

The results from the linear correlation analysis (the Pearson correlation coefficient) between the parameters of whole blood conductivity $\left(\sigma_{1}, \sigma_{2}\right)$, derived from eq. (1) at loading and ASTP are shown in Table 2. Linear positive correlation is found between $\sigma_{1}(\mathrm{mS} / \mathrm{cm})$ and $\sigma_{2}(\mathrm{mS} / \mathrm{cm})$ at high shear rates $\left(37,6 \mathrm{~s}^{-1}\right.$ and $\left.94,5 \mathrm{~s}^{-1}\right)$ and ASTP in the neurogenic frequency range, 3 minutes after the cold test $-\mathrm{N} 3(\mathrm{r} \approx 0,6)$. Linear negative correlation is found between the $\sigma_{1}(\mathrm{mS} / \mathrm{cm})$ and $\sigma_{2}$ $(\mathrm{mS} / \mathrm{cm})$ at high shear rates too $\left(37,6 \mathrm{~s}^{-1} \text { and } 94,5 \mathrm{~s}^{-1}\right)^{2}$ and ASTP in the myogenic frequency range, before the cold test $-\mathrm{M} 1(\mathrm{r} \approx-0,6)$. Significant linear negative correlation was found between $\sigma_{2}(\mathrm{mS} / \mathrm{cm})$ and calculated from the viscosity IAE index at loading from $0 \div 3,23 \mathrm{~s}^{-1}$ $(\mathrm{r}=0,999, \mathrm{p}=0,0206)$. The correlation analysis revealed significant $\sigma_{1-} \mathrm{T}_{k}$ and $\sigma_{2-} \mathrm{T}_{\mathrm{k}}(\mathrm{r} \approx-0.8, \mathrm{p}<0.05)$ correlation at high shear rates (Tabl. 2).

The conductivity parameters - the initial value of blood conductivity, the final value of the blood conductivity and the asymptotic final value of the blood conductivity $\left(\sigma_{1}, \sigma_{2} \sigma_{3}\right)$, derived from both equations (1) and (2) revealed high negative linear correlation with sodium at high shear rates $37,6 \mathrm{~s}^{-1}$ and $94,5 \mathrm{~s}^{-1}$, for both types of experiments evaluating the kinetics of whole blood conductivity at loading $(\mathrm{r} \approx-0,79 \div-0,83, \mathrm{p}<0.05)$ and at relaxation $(\mathrm{r} \approx-0,79 \div-0,86, \mathrm{p}<0.05)($ Tabl. $2 ; 3)$. Sodium usually forms ionic compounds involving the $\mathrm{Na}^{+}$cation. As a result, the total charge of blood, consisting of slightly electronegative erythrocytes in blood plasma decreased. This could explain the negative linear correlation of the parameters of the specific conductivity $\left(\sigma_{1}, \sigma_{2}, \sigma_{3}\right)$ with sodium at high shear rates, when the erythrocytes are oriented along the current lines. The conductivity parameters $\left(\sigma_{1}, \sigma_{2} \sigma_{3}\right)$ revealed strong linear correlations with each other (Tabl. 2;3).

The results from the linear correlation analysis (the Pearson correlation coefficient) between the parameters of whole blood conductivity $\left(\sigma_{2}, \sigma_{3}\right)$, derived 


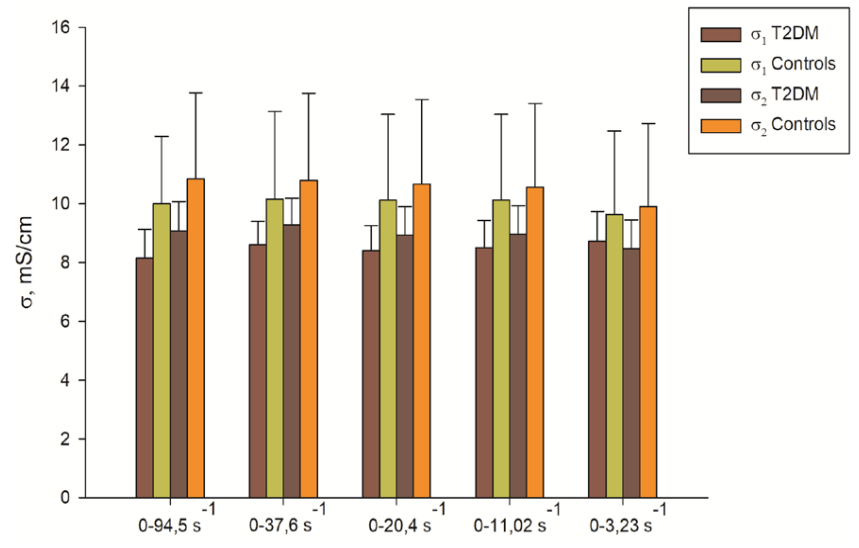

Fig. 3. Mean values and standard deviations of the parameters of the whole blood conductivity $\left(\sigma_{1}, \sigma_{2}\right)$, obtained from eq. (1) at loading from zero up to different shear rates in the group of T2DM $(n=13)$ and in healthy subjects $(n=9)$

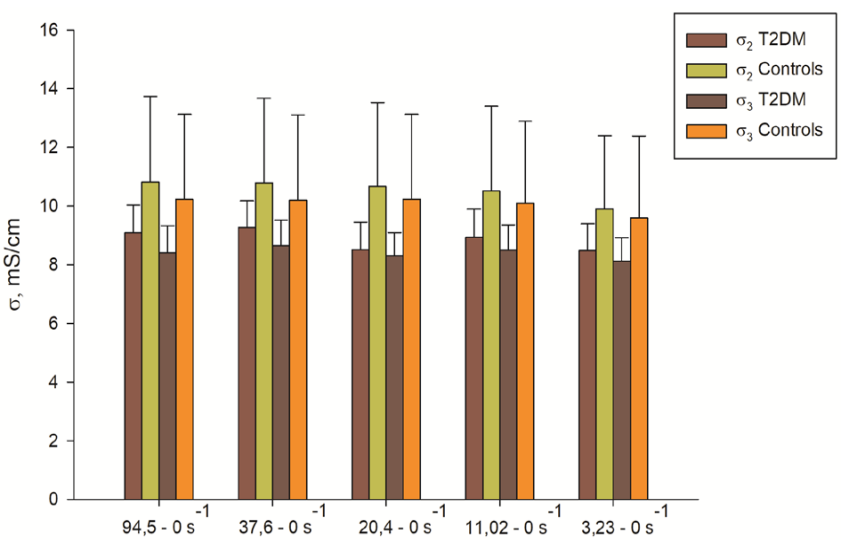

Fig. 4. Mean values and standard deviations of the parameters of whole blood conductivity $\left(\sigma_{2}, \sigma_{3}\right)$, obtained from eq. (2) at relaxation from different shear rates to zero in the group of T2DM patients $(n=13)$ and in healthy subjects $(n=9)$

Table 2

Pearson correlation coefficients obtained from the linear correlation analysis between the parameters of whole blood conductivity $\left(\sigma_{1}, \sigma_{2}\right)$, calculated from eq. (1) at loading and the amplitudes of the skin temperature pulsations (ASTP) in the myogenic (M1, before the cold test) and the neurogenic (N3, 3 minutes after the cold test) frequency ranges and microrheological parameters (IAE, Tk) and sodium (Na) in the group of patients with T2DM

\begin{tabular}{|c|c|c|c|c|c|c|c|c|}
\hline & & $\sigma_{2}(\mathrm{mS} / \mathrm{cm})$ & $\begin{array}{c}\sigma_{3}(\mathrm{mS} / \mathrm{cm}) \\
\text { (at relaxation) }\end{array}$ & N3 & M1 & $\mathrm{Na}, \mathrm{mmol} / \mathrm{l}$ & Тк & IAE \\
\hline \multirow[t]{2}{*}{$\begin{array}{l}\text { Shear rate } \\
0 \div 94,5 \mathrm{~s}^{-1}\end{array}$} & $\sigma 1(\mathrm{mS} / \mathrm{cm})$ & $\begin{array}{c}\mathrm{r}=0,992^{* * *} \\
(17)\end{array}$ & $\begin{array}{c}\mathrm{r}=0,996^{* * *} \\
(17)\end{array}$ & & $\begin{array}{c}\mathrm{r}=-0,591^{*} \\
(13)\end{array}$ & $\begin{array}{c}r=-0,833^{*} \\
(8)\end{array}$ & & \\
\hline & $\sigma_{2}(\mathrm{mS} / \mathrm{cm})$ & & $\begin{array}{c}\mathrm{r}=0,998^{\star * *} \\
(17)\end{array}$ & $\begin{array}{c}\mathrm{r}=0,554^{*} \\
(13)\end{array}$ & & $\begin{array}{c}r=-0,862^{* *} \\
(8)\end{array}$ & & \\
\hline \multirow[t]{2}{*}{$\begin{array}{l}\text { Shear rate } \\
0 \div 37,6 \mathrm{~s}^{-1}\end{array}$} & $\sigma_{1}(\mathrm{mS} / \mathrm{cm})$ & $\begin{array}{c}\mathrm{r}=0,998^{* * *} \\
(15)\end{array}$ & $\begin{array}{c}\mathrm{r}=1^{\star * *} \\
(15)\end{array}$ & $\begin{aligned} \mathrm{r}= & 0,614^{*} \\
& (12)\end{aligned}$ & $\begin{array}{c}\mathrm{r}=-0,654^{\star} \\
(12)\end{array}$ & $\begin{array}{c}r=-0,793^{*} \\
(8)\end{array}$ & $\begin{array}{c}\mathrm{r}=-0,627^{\star} \\
(13)\end{array}$ & \\
\hline & $\sigma_{2}(\mathrm{mS} / \mathrm{cm})$ & & $\begin{array}{c}\mathrm{r}=0,998^{\star * *} \\
(15)\end{array}$ & $\begin{aligned} \mathrm{r}= & 0,619^{*} \\
& (12)\end{aligned}$ & $\begin{array}{c}\mathrm{r}=-0,672^{\star} \\
(12)\end{array}$ & $\begin{array}{c}r=-0,792^{*} \\
(8)\end{array}$ & $\begin{array}{c}\mathrm{r}=-0,626^{*} \\
(13)\end{array}$ & \\
\hline \multirow[t]{2}{*}{$\begin{array}{l}\text { Shear rate } \\
0 \div 20,4 \mathrm{~s}^{-1}\end{array}$} & $\sigma_{1}(\mathrm{mS} / \mathrm{cm})$ & $\begin{array}{c}\mathrm{r}=0,996^{* * *} \\
(17)\end{array}$ & $\begin{array}{c}\mathrm{r}=0,656^{* * *} \\
(15)\end{array}$ & & & & $\begin{aligned} r= & -0,690^{*} \\
& (12)\end{aligned}$ & \\
\hline & $\sigma_{2}(\mathrm{mS} / \mathrm{cm})$ & & $\begin{array}{c}\mathrm{r}=0,676^{* * *} \\
(15)\end{array}$ & & & & $\begin{aligned} r= & -0,689^{*} \\
& (12)\end{aligned}$ & \\
\hline \multirow[t]{2}{*}{$\begin{array}{l}\text { Shear rate } \\
0 \div 11,02 \mathrm{~s}^{-1}\end{array}$} & $\sigma_{1}(\mathrm{mS} / \mathrm{cm})$ & $\begin{array}{c}\mathrm{r}=0,997^{* * *} \\
(13)\end{array}$ & $\begin{array}{c}\mathrm{r}=0,997^{* * *} \\
(10)\end{array}$ & $\begin{aligned} r= & 0,679^{*} \\
& (10)\end{aligned}$ & & & & $\begin{array}{c}\mathrm{r}=0,860^{* *} \\
(9)\end{array}$ \\
\hline & $\sigma_{2}(\mathrm{mS} / \mathrm{cm})$ & & $\mathrm{r}=0,994^{* * *}(9)$ & & & & & \\
\hline \multirow[t]{2}{*}{$\begin{array}{l}\text { Shear rate } \\
0 \div 3,23 \mathrm{~s}^{-1}\end{array}$} & $\sigma_{1}(\mathrm{mS} / \mathrm{cm})$ & $r=0,996^{*}(3)$ & $\begin{array}{c}\mathrm{r}=1^{\star * *} \\
(4)\end{array}$ & & & & & $\begin{array}{c}r=-0,957^{\star} \\
\text { (3) }\end{array}$ \\
\hline & $\sigma_{2}(\mathrm{mS} / \mathrm{cm})$ & & $\begin{array}{c}r=0,997^{*} \\
\text { (3) }\end{array}$ & & & & & $\mathrm{r}=-0,999^{*}$ \\
\hline
\end{tabular}

${ }^{*}-\mathrm{p}<0,05 ;{ }^{* *}-\mathrm{p}<0,01 ;{ }^{* *}-\mathrm{p}<0,001-$ significance differences.

from eq. (2) at relaxation and the amplitudes of the skin temperature pulsations ASTP are shown in Table 4. Moderate linear positive correlation is found between $\sigma_{2}$ $(\mathrm{mS} / \mathrm{cm})$ and $\sigma_{3}(\mathrm{mS} / \mathrm{cm})$ at high shear rates $\left(37,6 \mathrm{~s}^{-1}\right.$ and 94,5 $\mathrm{s}^{-1}$ ) and ASTP in the neurogenic frequency range, 3 minutes after the cold test $-\mathrm{N} 3(\mathrm{r} \approx 0,6, \mathrm{p}<0.05)$. Linear negative correlation is found between the $\sigma_{2}(\mathrm{mS} / \mathrm{cm})$ and $\sigma_{3}(\mathrm{mS} / \mathrm{cm})$ at high shear rates $\left(37,6 \mathrm{~s}^{-1}\right.$ and $\left.94,5 \mathrm{~s}^{-1}\right)$ and ASTP in the myogenic frequency range, before the cold test - M1 $(r \approx-0,6)$. Significant linear negative correlation was found between $\sigma_{3}(\mathrm{mS} / \mathrm{cm})$ and calculated from the viscosity IAE index at loading from $0 \div 3,23 \mathrm{~s}^{-1}$ $(\mathrm{r}=-0,999, \mathrm{p}=0,02)$ which means that at low shear rates with increasing of conductivity the erythrocyte aggregation is decreased. The correlation analysis revealed significant $\sigma_{1-} \mathrm{T}_{\mathrm{k}}$ and $\sigma_{2-} \mathrm{T}_{\mathrm{k}}(\mathrm{r} \approx-0.8)$ correlations at high shear rates (Tabl. 3). Moderate linear negative correlation was observed $\sigma_{3}$ Plt $(\mathrm{r} \approx-0,6)$ at $20,4 \mathrm{~s}^{-1}$ and high $(\mathrm{r} \approx-0,89)$ at $94,5 \mathrm{~s}^{-1}$.

Moderate negative linear correlations $(\mathrm{r}=0.4, \mathrm{r}=0.5$, $\mathrm{r}=0.6$ ) between the amplitudes of the skin temperature pulsations ASTP and the dynamic whole blood viscosity $(\eta)$ at a shear rate of $94.5 \mathrm{~s}^{-1}$ in the endothelial frequency range during the cold test $\left(\mathrm{T}_{\mathrm{E}} 2\right), 3$ min after $\left(\mathrm{T}_{\mathrm{E}} 3\right)$ and 10 min after it $\left(\mathrm{T}_{\mathrm{E}} 4\right)$ for the group of patients with T2DM were found (Tabl. 4). 
ОРИГИНААЬНЫЕ СТАТЬИ (кАинические исслеАования) / ORIGINAL ARTICLES (clinical investigations)

Table 3

Pearson correlation coefficients obtained from the linear correlation analysis between the parameters of whole blood conductivity $\left(\sigma_{2}, \sigma_{3}\right)$, obtained from eq. (2) at relaxation from five different shear rates to zero shear rate and the amplitudes of the skin temperature pulsations (ASTP) and some microrheological parameters as IAE and Tk and platelets (Plt) in the patients with T2DM

\begin{tabular}{|c|c|c|c|c|c|c|c|c|}
\hline & & $\sigma_{3}(\mathrm{mS} / \mathrm{cm})$ & N3 & M1 & $\mathrm{Na}, \mathrm{mmol} / \mathrm{l}$ & Тк & IAE & Plt $\cdot 10^{9} / 1$ \\
\hline \multirow[t]{2}{*}{$\begin{array}{l}\text { Shear rate } \\
94,5 \div 0 \mathrm{~s}^{-1}\end{array}$} & $\sigma_{2}(\mathrm{mS} / \mathrm{cm})$ & $\begin{array}{c}\mathrm{r}=0,998^{\star * *} \\
(17)\end{array}$ & $\begin{array}{c}r=0,554^{*} \\
(13)\end{array}$ & & $\begin{array}{c}r=-0,859^{* *} \\
(8)\end{array}$ & & & \\
\hline & $\sigma_{3}(\mathrm{mS} / \mathrm{cm})$ & & $\begin{array}{c}r=0,556^{*} \\
(13)\end{array}$ & $\begin{aligned} \mathrm{r}= & -0,553^{*} \\
& (13)\end{aligned}$ & $\begin{array}{c}\mathrm{r}=-0,857^{\star *} \\
(8)\end{array}$ & & & \\
\hline \multirow[t]{2}{*}{$\begin{array}{l}\text { Shear rate } \\
37,6 \div 0 \mathrm{~s}^{-1}\end{array}$} & $\sigma_{2}(\mathrm{mS} / \mathrm{cm})$ & $\begin{array}{c}\mathrm{r}=0,998^{\star * \star} \\
(15)\end{array}$ & $\begin{aligned} \mathrm{r}= & 0,614^{*} \\
& (12)\end{aligned}$ & $\begin{aligned} \mathrm{r}=- & -0,654^{\star} \\
& (12)\end{aligned}$ & $\begin{array}{c}\mathrm{r}=-0,793^{\star} \\
(8)\end{array}$ & $\begin{array}{c}\mathrm{r}=-0,627^{\star} \\
(13)\end{array}$ & & \\
\hline & $\sigma_{3}(\mathrm{mS} / \mathrm{cm})$ & & $\begin{array}{c}\mathrm{r}=0,619^{*} \\
(12)\end{array}$ & $\begin{array}{c}\mathrm{r}=-0,672^{*} \\
(12)\end{array}$ & $\begin{array}{c}\mathrm{r}=-0,792^{*} \\
(8)\end{array}$ & $\begin{array}{c}r=-0,626^{*} \\
(13)\end{array}$ & & \\
\hline \multirow[t]{2}{*}{$\begin{array}{l}\text { Shear rate } \\
20,4 \div 0 \mathrm{~s}^{-1}\end{array}$} & $\sigma_{2}(\mathrm{mS} / \mathrm{cm})$ & $\begin{array}{c}\mathrm{r}=0,997^{\star * *} \\
(15)\end{array}$ & & & & & & \\
\hline & $\sigma_{3}(\mathrm{mS} / \mathrm{cm})$ & & & & & & & $\begin{aligned} r= & -0,658^{*} \\
& (11)\end{aligned}$ \\
\hline $\begin{array}{l}\text { Shear rate } \\
11,02 \div 0 \mathrm{~s}^{-1}\end{array}$ & $\sigma_{2}(\mathrm{mS} / \mathrm{cm})$ & $\begin{array}{c}r=0,992^{* * *} \\
(10)\end{array}$ & & & & & & \\
\hline \multirow[t]{2}{*}{$\begin{array}{l}\text { Shear rate } \\
3,23 \div 0 \mathrm{~s}^{-1}\end{array}$} & $\sigma_{2}(\mathrm{mS} / \mathrm{cm})$ & $\mathrm{r}=0,996^{* * *}(8)$ & & & & & $\begin{array}{c}r=-0,850^{*} \\
(6)\end{array}$ & \\
\hline & $\sigma_{3}(\mathrm{mS} / \mathrm{cm})$ & & & & $\begin{array}{c}\mathrm{r}=-1,000^{*} \\
(3)\end{array}$ & & & $\begin{array}{c}r=-0,892^{*} \\
(6)\end{array}$ \\
\hline
\end{tabular}

Table 4

Pearson correlation coefficients obtained from the linear correlation analysis between the dynamic whole blood viscosity $(\eta)$ at a shear rate of $94.5 \mathrm{~s}^{-1}$ and the amplitudes of the skin temperature pulsations (ASTP) in the endothelial frequency range during the cold test (TE2), 3 min after (TE3) and 10min after it (TE4) for the group of patients with T2DM

\begin{tabular}{c|c|c|c}
\hline$\eta, \mathrm{mPa} . \mathrm{s}$ & TE2 & TE3 & TE4 \\
\hline$\dot{\gamma}=94.5 \mathrm{~s}-1$ & $\mathrm{r}=-0.560^{\star \star}$ & $\mathrm{r}=-0.669^{\star \star}$ & $\mathrm{r}=-0.438^{\star}$ \\
${ }^{*}-\mathrm{p}<0,05 ;{ }^{* *}-\mathrm{p}<0,01-$ significance in comparison to controls.
\end{tabular}

\section{Discussion}

Using novel approaches, methods and tools, impairments of the rheological and electrical properties of the blood (plasma and blood viscosity, blood conductivity) under different flow conditions and modes of steady and unsteady flow in the group of patients with diabetes mellitus type 2 (T2DM) have been determined. Peripheral vasomotor reactivity and vascular endothelial function in patients with type 2 diabetes mellitus using WAST method were analyzed too. Correlations, characterizing the relationships between the blood rheological and conductivity parameters, obtained from approximation of experimental data and the micromechanical properties of the blood cells as well as the parameters of microvascular tone regulation in T2DM patients have been searched.

The methodology for diagnosing the peripheral microcirculation based on the wavelet analysis of data from the contact thermometry (WAST) method was used to estimate disturbances of the mechanisms of regulation of the vascular tone in patients with type 2 diabetes mellitus. We used the contralateral cold test, as one of the pathogenetical tests to assess microvascular function
[17]. Dysregulation of microvascular tone in patients with type 2 diabetes mellitus is accompanied by disturbances of the rheological and electrical characteristics of blood, which presumably is a complex manifestation of endothelial dysfunction.

Two sigmoidal equations were applied to describe the kinetics of blood conductivity. Both models include conductivity parameters $\left(\sigma_{1}, \sigma_{2}, \sigma_{3}\right)-\sigma_{l}, \sigma_{2}$ are the initial asymptotic value of the blood conductivity; $\sigma_{3}$ is the final asymptotic value of the blood conductivity and time indices too. The Pearson correlations between these parameters and the ASTP in the frequency ranges, corresponding to the myogenic, neurogenic, and endothelial mechanisms of the microcirculation tone regulation were analyzed. The correlation analysis revealed good ASTP $-\left(\sigma_{1}, \sigma_{2}, \sigma_{3}\right)$ relationships in the neurogenic range 3 minutes after the cold test, while the ASTP $-\left(\sigma_{1}, \sigma_{2}\right.$, $\sigma_{3}$ ) correlation in the myogenic frequency range before the cold test was negative $(\mathrm{r}<-0.8, \mathrm{p}<0.5)$.

Several authors have studied the electrical properties of blood and blood cells in patients with type 2 diabetes mellitus. Using a new method based on the dielectric 
properties of disperse systems and blood admittance measurements abnormal erythrocyte aggregability was determined in diabetic patients [18]. The authors found a significantly higher sensitivity of the method to detect enhanced RBC aggregation than techniques based on the phenomenon of light scattering, microscopic observations, and others. Zilberman-Kravits et al. also found in [18] that aggregability is increased in type $1 \mathrm{DM}$ and even more markedly in type 2 diabetic patients. The enhanced $\mathrm{RBC}$ aggregation in type 1 diabetes was significantly correlated with the levels of HBA1C, cholesterol and triglycerides. However, no correlation between metabolic control and RBC aggregability was found in T2DM.

Rheological and electrical behavior of blood in patients with diabetes mellitus type 2 is studied by O. Desouky [19]. The obtained results show that there is an increase in rheological properties (viscosity and yield stress) and electrical properties (dielectric constant, dielectric loss, relaxation time and AC conductivity) of diabetic erythrocytes compared to healthy individuals. The authors suggest that rheological disorders of diabetic erythrocytes (increased aggregation and decreased deformability) will cause microvascular complications of diabetes [19].

The feasibility of differential diagnosis of the degrees of rheological disturbances in patients with T2DM by dielectrophoresis of erythrocytes has been investigated by Kruchinina et al. [20]. By applying this method, the authors found different changes of several rheological parameters of the erythrocytes, their combined interpretation showing high sensitivity and specificity for diagnosis of rheological disturbances in T2DM. They emphasize that the study of more than 20 parameters of erythrocytes like decrease in deformation amplitude, dipole moment, polarizability and membrane capacity and increase in conductivity, viscosity, rigidity, hemolysis, and formation of aggregates, allows assessment of local and systemic microcirculation. Our findings for increased whole blood viscosity at high shear rates in T2DM patients are in accordance with the results of Kruchinina et al. for raised internal viscosity and summarized rigidity of RBCs.

\section{Conclusion}

Impairments of the rheological and electrical properties of the blood (plasma and blood viscosity, blood conductivity) under different flow conditions and modes of steady and unsteady flow in a group of patients with diabetes mellitus type 2 (T2DM) and in a control group of healthy subjects were found. The changes of the skin blood flow responses to cold stress in T2DM patients through wavelet analysis of the peripheral skin temperature pulsations were found and their relationship with the blood viscosity and blood conductivity parameters were estimated.

The simulation results and their comparison with the experimental data obtained in the study will allow us to search specific parametric models, which can reliably describe the main distinguishing features of the micromechanics of blood cells, its rheology, the microcirculation impairments in patients with diabetes mellitus type 2 (T2DM). They could be used in the study of microvascular and hemorheological complications in patients with various forms of pathology. These methods are based on the high sensitivity of the measured characteristics and the ability to detect pathological deviations.

The combination of these tests with an easy-to-perform technique (WAST method), could be successfully applied in the routine clinical practice to detect vascular complications in the patients with T2DM. The data from the results obtained are of interest and indicative of disorders associated with vasodilation and vasoconstriction of the peripheral vessels due to the endothelial dysfunctions.

\section{Acknowledgements}

The study has been supported by the project № КП06-H27/13 from 2018: «Development of experimental microfluidic system and methodology for the assessment of the microrheological properties of blood. Analysis of the peripheral vasomotor reactivity and vascular endothelial functions in patients with type 2 diabetes mellitus», funded by the Bulgarian National Science Fund.

The work has been supported also by the National Program «Young Scientists and Postdoctoral Students» of the Ministry of Education and Science, Project: «Development of non-invasive methodology and tools for assessment of regulatory mechanisms in patients with metabolic syndrome».

The authors also thank Acad. S. Podtaev from the Institute of Continuous Media Mechanics at UB of the Russian Academy of Sciences, Perm, Russia for providing the devices «Microtest», for the training for work and examining patients, for conducting research results, as well as for the instruction for working with various program options.

\section{Conflict of interest}

The authors declare no conflict of interest.

\section{References}

1. Velcheva I, Stoyneva Z, Antonova N, Damianov P, Kostova V, Dimitrova V. Skin hemodynamics and temperature oscillations in diabetic patients. Relation to blood rheology. J. Clin. Hemorheology and Microcirculation. 2013;167. Doi: 10.3233/CH-131750.

2. Velcheva I, Damianov P, Mantarova S, Antonova N. Cold pressor test: Effects on cardiac autonomic control and cerebral hemodynamic response in patients with diabetes mellitus type 2. Series on Biomechanics, 2012;27(1-2):64-69. ISSN:1313-2458.

3. Allen J, Howell K. Microvascular imaging: techniques and opportunities for clinical physiological measurements. Physiol Meas. 2014;(35):91-141. Doi: 10.1088/0967-3334/ 35/7/R91.

4. Kvandal P, Landsverk A, Bernjak A, Stefanovska A, Kvernmo D, Kirkebøen A. Low-frequency oscillations of the laser Doppler perfusion signal in human skin. Microvasc Res. 2006;72(3):120-127. Doi: 10.1016/j.mvr.2006.05.006.

5. Shusterman V, Anderson P, Barnea O. Spontaneous skin temperature oscillations in normal human subjects. Am J Physiol. 1997;(273):1173-1181.

6. Podtaev S, Morozov M, Frick P. Wavelet-based correlations of skin temperature and blood flow oscillations. Cardiovasc Eng. 2008;8(3):185-189. Doi: 10.1007/s10558-008-9055-y.

7. Isii Y, Matsukawa K, Tsuchimochi H, Nakamoto T. Icewater hand immersion causes a reflex decrease in skin temperature in the contralateral hand, J Physiol Sci. 2007;57(4):241248. Doi: 10.2170/physiolsci. RP007707. 
8. Smirnova E, Podtaev S, Mizeva I, Loran E. Assessment of endothelial dysfunction in patients with impaired glucose tolerance during a cold pressor test. Diab Vasc Dis Res. 2013; 10(6):489-497. Doi: 10.1177/1479164113494881

9. Kostova V, Antonova N, Chaushev N, Velcheva I, Ivanov I. Oscillations in skin temperature after cold test in patients with type 2 diabetes mellitus and rheological properties of the blood, J Series on Biomechanics. 2015;29(1):11-16.

10. Antonova N, Tsiberkin K, Podtaev S, Paskova V, Velcheva I, Chaushev N. Comparative study between microvascular tone regulation and rheological properties of blood in patients with type 2 diabetes mellitus. Clinical Hemorheology and Microcirculation. 2016;64(4):837-844. Doi: 0.3233/CH-168000,837-844.

11. Antonova N, Riha P, Ivanov I. Time dependent variation of human blood conductivity as a method for an estimation of RBC aggregation. Clinical Hemorheology and Microcirculation. 2008;(39):69-78.

12. Kaliviotis E, Ivanov I, Antonova N, Yianneskis $M$. Erythrocyte aggregation at non-steady flow conditions: A comparison of characteristics measured with electrorheology and image analysis. Clinical Hemorheology and Microcirculation. 2010;44(1):43-54. Doi: 10.3233/CH-2009-1251.

13. Ройтман Е., Фирсов Н., Дементьева М. и др. Термины, понятия и подходы к исследованиям реологии крови в клинике. Тромбоз, гемостаз и реология. - 2000. T. 3, № 3. - C. 5- 12. [Roitman E, Firsov N, Dementyeva M, Samsonova N, Plyushch M, Vorobieva N. Terms, concepts and approaches to the study of blood rheology in the clinic. Thrombosis, Hemostasis and Rheology. 2000;3(3):5-12. (In Russ.)]

14. Dintenfass L. Red cell rigidity, "Tk» and filtration. Clinical Hemorheology. 1985;(5):241-244.

15. Paskova V, Antonova N, Ivanov I, Velcheva I, Chaushev N. Rheological and electrical behaviour of blood in patients with diabetes mellitus type 2. Series on Biomechanics. 2019;33(1):51-58.

16. Antonova N. Methods in hemorheology and their clinical applications. Clinical Hemorheology and Microcirculation. 2016;(64):509-515. Doi: 10.3233/CH-168001.
17. Frick P, Grossmann A, Tchamitchian P. Wavelet analysis of signals with gaps, J Math Physcs. 1998;(39):4091-4107. Doi: 10.1063/1.532485.

18. Zilberman-Kravits D, Harman-Boehm I, Shuster T, Meyerstein $N$. Increased red cell aggregation is correlated with HbA1C and lipid levels in type 1 but not type 2 diabetes. Clinical Hemorheology and Microcirculation. 2006; 35(4):463-471.

19. Desouky O. Rheological and electrical behavior of diabetes mellitus, Romanian J. Biophys. 2009;19(4):239-250.

20. Kruchinina MV, Gromov AA, Generalov VM, Kruchinin VN. Possible differential diagnosis of the degrees of rheological disturbances in patients with type 2 diabetes mellitus by dielectrophoresis of erythrocytes, J. Pers. Med. 2020;(10):60. Doi: 10.3390/jpm10030060.

\section{Information about authors}

Nadya Mladenova Antonova - PhD, Professor, Department of Biomechanics, Institute of Mechanics, BAS, Sofia, Bulgaria, e-mail: antonova@imbm.bas.bg, ORCID:0000-0003-1707-0235.

Vasilka Krumova Paskova - PhD, Assistant, Department of Biomechanics, Institute of Mechanics, BAS, Sofia, Bulgaria, ORCID: 0000-0003-1398-5614.

Irena Vassileva Velcheva - Ph. D., Associate Professor, Clinic of nervous diseases, Uni Hospital Panagyurishte, Bulgaria, e-mail: velchevairena@gmail.com, ORCID: 0000-0003-1464-7385.

\section{Информация об авторах}

Антонова Наця Млаценова - АОктор (кандицат технических наук), профессор кафедры биомеханики, Институт механики БАН, Софрия, Болгария, e-mail: antonova@imbm.bas.bg, ORCID: 0000-0003-1707-0235.

Паскова Василка Крумова - Аоктор по биомеханике (канмихат наук по биомеханике), ассистент кафредры биомеханики, Институт механики БАН, София, Болгария, ORCID: 0000-0003-1398-5614.

Вемчева Ирена Василева - доктор (кандидат медицинских наук), Аоцент, клиника нервных заболеваний, Уни Хоспитал, Панагюрище, Болгария, e-mail: velchevairena@gmail.com, ORCID: 0000-0003-1464-7385. 